See discussions, stats, and author profiles for this publication at: http://www.researchgate.net/publication/263473926

\title{
The impact of online media on stakeholder engagement and the governance of corporations
}

ARTICLE in JOURNAL OF PUBLIC AFFAIRS · JUNE 2014

DOI: 10.1002/pa.1535

CITATION

1

2 AUTHORS:

Christian Pieter Hoffmann

University of St.Gallen

79 PUBLICATIONS 29 CITATIONS

SEE PROFILE
READS

69
Christoph Lutz

University of St.Gallen

30 PUBLICATIONS 24 CITATIONS

SEE PROFILE 


\title{
Academic Paper
}

\section{The impact of online media on stakeholder engagement and the governance of corporations}

\author{
Christian Pieter Hoffmann* and Christoph Lutz \\ Institute for Media and Communications Management, University of St. Gallen, St. Gallen, Switzerland
}

\begin{abstract}
Online tools such as social media provide new opportunities for citizens and stakeholder groups to be informed, identify common interests, express and share opinions and demands, organize, and coordinate interventions. Therefore, the Internet could be expected to increase stakeholder engagement in corporate affairs and facilitate good governance. In order to provide an overview of current findings on the impact of online media on governance and stakeholder engagement, we conduct a systematic literature review. Our analysis reveals five topical categories of inquiry. We analyze studies from the field of business participation and find a strong bias towards consumer engagement and marketing issues. Only few studies are found to critically explore the effect of online media on power and value distribution between corporations and stakeholders. We then turn to the more established field of political and civic participation in order to further analyze antecedents, forms, and outcomes of online engagement in civic affairs, and derive a framework for future research. Copyright @ 2014 John Wiley \& Sons, Ltd.
\end{abstract}

\section{INTRODUCTION}

In an enthusiastic review of the Internet's political impact, Clay Shirky (2011) writes: 'social media have become coordinating tools for nearly all of the world's political movements'. This might be somewhat optimistic, but in fact, research has been quick to explore the notion that new technologies will facilitate political participation and create access for non-elite citizens (Davis, 1999; Hacker, 1996; Stromer-Galley, 2000). Online media not only make citizen participation in political decision making logistically feasible, they also support deliberative processes by providing access to a wide range of information and online conversations (White, 1997; DiMaggio et al., 2001; Stromer-Galley \& Foot, 2002). A range of studies have therefore explored the impact of online media on citizen participation.

*Correspondence to: Christian Pieter Hoffmann, Institute for Media and Communications Management, University of St. Gallen, Blumenbergplatz 9, St. Gallen, Switzerland, 9000.

E-mail: christian.hoffmann@unisg.ch
Nisbet et al. (2012) find that Internet use increases demand for democracy. A meta-analysis by Boulianne (2009) also finds evidence for a positive effect of Internet use on political engagement. Social media use, too, has been linked to political interest, online and offline civic as well as political participation (Vitak et al., 2011; Towner \& Dulio, 2011; Gil de Zuniga et al., 2010). So if online media do in fact increase citizen engagement in public governance, how does this translate to the governance of market institutions? Will the Internet also contribute to more active, critical, and engaged stakeholders? Do they provide new opportunities for good governance?

To date, research on citizen participation is focused on issues of public governance (Andersen et al., 2011; Ebbers et al., 2008; Heeks \& Bailur, 2007). Yet, there are significant similarities between citizen participation in public and corporate governance: both are characterized by hierarchical decision-making processes, a delegation of power to professionals and select committees, and a strong asymmetry of power between professional decision makers and members of various interest groups 
(Rowson et al., 2010). If these hierarchies and asymmetries are shaken up in the public sphere by citizens' use of online media, similar effects should be expected in the corporate sphere (Roper, 2002).

Cyert and March (1963) famously describe corporations as coalitions and sub-coalitions of individuals sharing similar interests. Stakeholder theory 'views the corporation as an organizational entity through which numerous and diverse participants accomplish multiple, and not always entirely congruent, purposes' (Donaldson \& Preston, 1995, p. 70). A key purpose of corporate leadership, therefore, is the coordination of and arbitration between various interest groups vying for corporate attention and resources and competing for influence on the corporate agenda (Mintzberg, 1979; Starbuck, 1983; Noda \& Bower, 1996). Corporate governance can be understood as a system of rules, practices, and processes by which a corporation is directed and controlled. At its heart, it involves the alignment of interests among key stakeholders (Goergen, 2012). If online media affect the communication, coordination, and organization of interest groupsas suggested by current research in political participation-effects on corporate governance are to be expected.

In summary, participation research implies that social media impact and stimulate civic and/or political engagement and thereby public governance. There are reasons to believe that social media could similarly affect governance in the business domain. In order to explore the extent and forms of online media's impact on stakeholder engagement in corporate affairs, the authors conducted a systematic literature review. Various forms of stakeholder participation through online media, key antecedents, and outcomes will be analyzed and future research opportunities identified.

\section{THEORETICAL BACKGROUND}

Companies are increasingly expected to assume responsibility for a broad range of social and environmental concerns (Carroll, 1979; Carroll \& Buchholtz, 2006). However, as Clarkson (1995) points out, managers can more easily address requirements of specific interest groups or 'stakeholders' than abstract social policy. Thus, in order to achieve good governance and manage complex social or environmental tasks, it is crucial for corporations to establish constructive relationships with their stakeholders (De Beer \& Rensburg, 2011).

Krick et al. (2005) differentiate three generations of stakeholder engagement: in a first generation, companies were primarily responding to the pressure of interest groups in order to prevent bad publicity. The second generation was characterized by a more proactive approach-companies strove to increase their understanding of the business environment through stakeholder engagement. In an emerging third generation, companies are expected to incorporate stakeholder engagement into their governance structures in order maintain strategic competitiveness by aligning social, environmental, and economic performance (c.f. Andriof \& Waddock, 2002; Burchell \& Cook, 2008).

Of course, integrating stakeholder relations into governance requires the identification of relevant and legitimate stakeholders. Companies have to decide how much attention (and resources) to devote to groups such as customers, shareholders, employees, local communities, or NGOs (Freeman, 1984; Post et al., 2002). Without a proper differentiation of relevant stakeholders, companies run the risk of continually engaging the 'usual suspects' or the loudest voices. Pedersen (2006) therefore describes stakeholder engagement as a process involving several 'filters' - such as choosing the right interaction partners and defining adequate responsibilities. This task will become more complex as online media facilitate the coordination and activation of more diverse, at times only temporary, interest groups.

Social media make it easy for non-professional users to share content, which is held to contribute to a more level playing field in public agenda setting (Roper, 2002; Towner \& Dulio, 2011; Wattal et al., 2010). Social media have been particularly powerful in connecting likeminded individuals, providing an infrastructure for communities of interest (Wilson \& Peterson, 2002; Van den Broek et al., 2012). Applications like social network websites allow pursuers of political and social interests to join conversations (Woodly, 2007; Gil de Zuniga et al., 2010), and to bond with peers sharing similar views (Steinfield et al., 2008). Also, social media are held to reduce transaction and coordination costs, making it easier for likeminded citizens to organize around common interests (Nie et al., 2010; Donath \& boyd, 2004). Therefore, it would seem reasonable to assume that online media will have an impact on stakeholder engagement in corporations' governance, too.

Today, there is a noticeable lack of clearly defined structures and processes in the field of stakeholder engagement (O'Riordan \& Fairbrass, 2008; De Beer \& Rensburg, 2011). Some critical antecedents of stakeholder engagement emerge from current research, such as pressure exerted by stakeholder groups (Andriof \& Waddock, 2002; Carroll \& 
Buchholtz, 2006), formalization of procedures and coordination across departments (Pedersen, 2006), and continuous relationship-building (Burchell \& Cook, 2008). Little is known about the opportunities and challenges of online media for stakeholder engagement, though. This study sets out to extend current insights in online participation to the field of stakeholder engagement and corporate governance. We conduct a systematic literature analysis in order to gain a deeper understanding of the dynamics of online participation in corporate affairs and analyze their antecedents as well as outcomes. Based on these insights, propositions for future research will be derived.

\section{METHODOLOGY}

The authors conducted a systematic literature review, following a six-step approach: in the first step, four databases were searched based on a number of pertinent key words. ISI Web of Science, EBSCO, and ProQuest were chosen as core databases. In addition, in order to include a medium more reliant on user participation, Mendeley was chosen as a fourth database. The search was based on six keywords: 'Online' or 'Internet' or 'Digital' or 'Social Media' and 'Participation' or 'Engagement'. In order to limit the number of results, the search was restricted to the publications' title; also, the search was limited to peer-reviewed publications in the English language. The search resulted in 1.806 hits.

In the second step, the authors removed 840 multiple entries. Third, paper abstracts were scanned, 295 clearly irrelevant papers were removed. In the fourth step, papers were categorized according to their field of inquiry, resulting in five distinct research areas: political / civic (286), business (63), cultural (21), health (64), and education participation (219) (Figure 1). The field of health participation focuses on the engagement of patients and their participation in therapeutic processes. Similarly, the field of education participation focuses on the engagement of students and participation in the teaching process. Finally, the small category termed 'cultural participation' explores the impact of online media on art projects and the participation in cultural self-expression. The authors deemed these questions too far removed from the research question at hand and therefore excluded these papers from further analysis.

In the fifth step, the remaining papers from the fields of business and political/civic participation were thoroughly analyzed. In this process, another set of papers was excluded: some papers addressed users' engagement with the Internet in general, literacy, and use divides. These questions were deemed too broad to contribute to the research question at hand. Another group of papers focused very narrowly on means to increase user engagement in one specific online platform. In the end, 162 articles -15 on business participation, specifically, and 147 on political/civic participation-were analyzed as to their focus, research methodology, key concepts, and results. Findings from the analysis will be outlined in the succeeding text. First, we will focus on findings derived from studies on business participation. These findings will then be complemented by insights from the more established and elaborate field of political/civic participation.

\section{RESULTS}

\section{Initial overview}

Our literature review reveals that online participation in the context of political or civic engagement is a much more established field of inquiry than in a business context. Figure 2 exhibits the number of pertinent articles identified in both categories. The graph shows that academic interest in online participation took off in the beginning of the 2000s, around the time when a significant number of people started using the Internet regularly. From 2007 on, the volume of studies addressing online participation increases again, which may be related to the rise of social media. The oldest publication in our sample from the business category dates from 2005. This constitutes a considerable time-lag compared with the political/civic participation category.

\section{Participation in corporate affairs}

Among the papers focusing on engagement in business affairs, a large majority focus on the participation of customers. Thereby, we find a distinct marketing bias among studies addressing the impact of online media on stakeholder engagement. A number of papers address potential improvements to customer service facilitated by new media. These studies explore how online media allow businesses to strengthen exchange relationships with their customers in the vein of relationship marketing (Dabholkar \& Sheng, 2012; Sashi, 2012). Studies find that new media allow for more interactivity and richness in these exchange relationships.

The engagement of customers in productive processes has been addressed under labels such as 'co-creation' or the evolvement of the 'prosumer' 


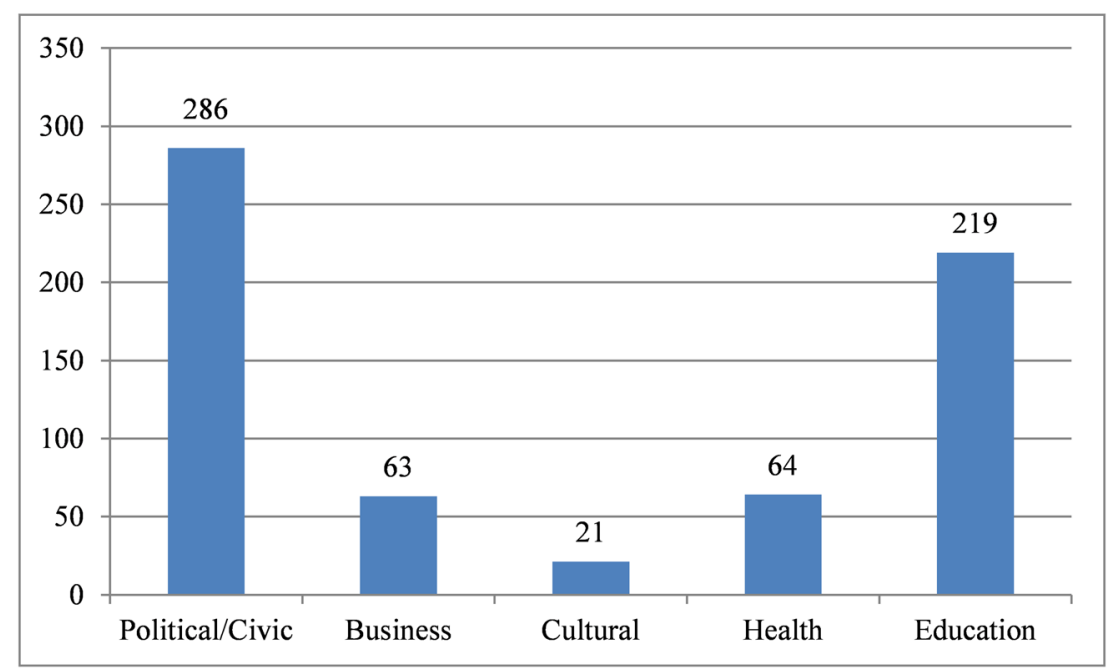

Figure 1 Areas of participation through online media (numbers of articles found)

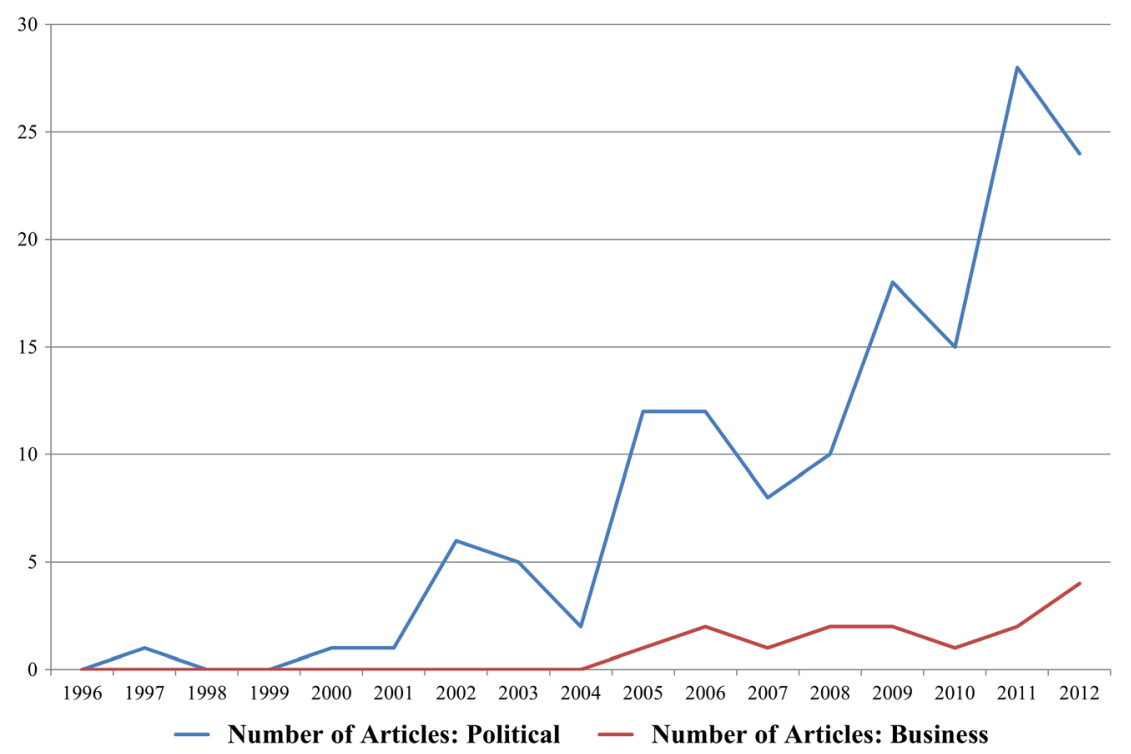

Figure 2 Number of publications per year $(N=158$, four articles from 2013 not included)

(Ramaswamy, 2008; Sawhney et al., 2005; Chaney, 2012). The underlying hypothesis here is that new media facilitate the interaction of producers and consumers and allow for the collaborative creation of value. Participation in this sense goes beyond a mere customization or personalization of a product or service (c.f. Chang et al., 2009). New media allow for creative input of the consumer into the development ('open innovation'), design, and production of business offers (Ramaswamy, 2008; Franquet et al., 2011).

These engagement processes are rarely considered in political terms-in other words, the literature focuses on benefits to both businesses and consumers made possible by new media. Whether and to what degree these changes constitute a shift in control and power is barely ever problematized (cf. Roper, 2002). This is somewhat surprising as consumer participation in product or service creation may in fact shift control from the corporation to the consumer (Riegner, 2007; Chang et al., 2009). Of course, such an effect is contingent upon a number of conditions, such as the current state, culture and strategy of the corporation, the motivation and power of stakeholders, and the governance of the engagement process (Powell et al., 1996; Gulati, 1998; Tether, 2002). A popular concept in this context is the corporation's 'absorptive capacity', its ability to recognize and assimilate critical input from external sources (Cohen \& Levinthal, 1990).

A number of studies in this field focus on the role of user communities in the creation of open source 
software (Hertel et al., 2003; Lakhani \& Von Hippel, 2003). Here, corporations have found that consumers are willing and able to independently create highquality solutions (i.e., through peer production) that successfully compete with their own offers-and accordingly strive to incorporate this form of user engagement into their own value creation. Still, only few studies notice that customer participation entails a form of value redistribution-commonly increasing the benefit received by the customer (Harhoff et al., 2003), in some cases decreasing the benefit available to the business (Chaney, 2012), in others providing new value potentials (Franquet et al., 2011).

Noticeably, a number of papers focus on creative industries, such as journalism or music. These industries are especially receptive to changes in consumer-producer interaction brought about by new media, as their output is based on the application of media technology (Franquet et al., 2011). Online media may disrupt established business models as consumers begin to produce artifacts that previously, because of significant production and distribution costs, used to be the domain of professional suppliers (Chaney, 2012; Nguyen, 2006). Examples can be found in the emergence of new media outlets such as the Huffington Post and Gawker Media or multi-channel networks operating on Youtube, such as Maker Studios. Established players in the creative industries adapt by increasingly sourcing content from their audiences and closely monitoring audience reactions (Jeppesen \& Frederiksen, 2006).

At the same time, the overall effect of social media on corporate governance in the creative industries may be ambivalent as consumer 'empowerment' may well increase consumer loyalty by creating a 'buy-in' into co-created content (Chaney, 2012). Examples would be user comments on newspaper websites or 'citizen journalism' input into established news organizations, such as the $\mathrm{CNN}$ iReport program. Thereby, power realignments due to consumer participation may be moderated by consumers' sense of belonging to the organization they engage with ('organizational citizenship') (Yen, 2011).

Another concept addressed by a number of studies is the 'advocacy' of customers, primarily in the sense of word-of-mouth promotion (Riegner, 2007; Chaney, 2012). Advocacy is achieved when 'delighted or loyal customers share their delight or loyalty in interactions with others in their social networks' (Sashi, 2012, p. 264). Only one study addresses potential dangers in businesses misusing or opposing word-of-mouth promotion by consumers (Campbell et al., 2012). Again, customer engagement is not explored as a challenge to corporate autonomy or power-none of the studies identified in our analysis addresses the impact of new media on 'advocacy' in the sense of critical issues advocacy or stakeholder pressure on businesses.

One study explored the potential of online media for stakeholder engagement in a more traditional sense: Adams and Frost (2006) analyze the use of online tools for communicating social and environmental performance to stakeholders. The authors find that businesses' online tools are primarily geared towards customers and shareholders. The use of corporate websites for sustainability reporting is not considered a high priority. Another paper considers the impact of social media on businesses' community relations (Kane et al., 2009). It finds that social media allows communities to share knowledge and monitor corporate behavior while simultaneously shortening the available response time for corporations. Also, social media allow dispersed audiences to organize as coherent interest groups more effectively.

Finally, one study analyzed an effect of Internet use on stakeholder engagement that may be of significant importance to governance: Bogan (2008) finds that Internet use is associated with stronger participation in the stock market. The author theorizes that online media provide pertinent information to potential shareholders and facilitate access to banking institutions. Online media may therefore directly impact formal control over corporate affairs.

In order to derive further insights into the effect of online media on stakeholder engagement and governance, a better understanding of the drivers and dynamics of online participation is necessary. This understanding needs to go beyond a narrow focus on just customers as potential engagers of corporations. We therefore set out to develop a research framework that provides a broad basis for the analysis of the Internet's effect on stakeholder engagement and governance. The more established research field of political/civic participation provides some valuable insights that, applied to the corporate domain, allow for substantiated research propositions.

\section{Insights from political/civic participation and research propositions}

A first, fundamental issue addressed by a number of studies is the question of whether the Internet actually weakens or strengthens citizens' civic and political participation. An early, 'utopian' view optimistically proclaimed that the web will clearly increase citizens' propensity to engage (Wellman 
et al., 2001). The opposing view-sometimes termed the 'displacement hypothesis' - expected Internet use to undermine citizen engagement as people dwindle away their time staring at computer screens (Putnam, 1995). Finally, a third perspective, often called the 'normalization thesis', posits that the Internet would not change participation patterns in either direction, but rather reinforce established power structures (Jennings \& Zeitner, 2003; Krueger, 2002).

In recent years, a wide range of studies have addressed these propositions empirically. Several of those found a positive effect of Internet use on offline political and civic engagement (Bakker \& De Vreese, 2011; Di Gennaro \& Dutton, 2006; Stern \& Dillman, 2006). A meta-analysis of 38 studies conducted by Boulianne (2009) found evidence for a moderate positive effect of the web on offline political and civic engagement. Similarly, a literature overview by Anduiza et al. (2009) indicates a stronger link between Internet use and online political participation than between Internet use and offline political participation.

Qualitative investigations also indicate a positive effect of the web on participation (e.g. Davis, 2010; Gil De Zuniga et al., 2010). However, they contribute further context to the discussion by differentiating various forms of participation and engagement. Findings indicate that, whereas the web might not have a strong impact on traditional forms of political engagement-such as contacting politicians or voting - it might well encourage and strengthen new, more action-oriented and case-based forms of engagement. The strongest impact of Internet use therefore may emerge from new forms of stakeholder activism outside of established institutions (Dahlgren, 2011).

Research Proposition 1: Overall, Internet use is positively associated with users' propensity to engage corporations online.

Research Proposition 2: Users' propensity to engage corporations online is weakly, but positively associated with their propensity to participate in corporations' offline governance processes.

When analyzing the effect of online media on stakeholder engagement, it is important to differentiate specific kinds of internet use. Blanket measures of Internet use, like time spent online, do not take account of how specific web uses might differ in their impacts on participation. Bakker and de Vreese (2011) found that using the Internet for information purposes, such as news consumption, is positively associated with both online and offline participation, whereas consuming media for entertainment purposes is negatively related to participation (Wang, 2007). Moy et al. (2005) differentiate seven types of Internet use: information, e-mail, household, political, consumer, social, and community uses. Of these, information, e-mail, political, and community uses are positively associated with civic engagement. Social forms of using the web also seem to foster engagement and participation: Dutta-Bergman's (2006) study showed that users who were active in online discussion forums and communities in the wake of $09 / 11$ were able to transfer this activity to the offline world and were more active in local communities.

Research Proposition 3: Whereas informational and social Internet uses are positively associated with users' propensity to engage corporations online, entertainment uses exert a negative influence.

Social media, especially, allow for more dynamic social uses of the web. Social media make it easy to find likeminded users and associate with peers sharing similar views (Wilson \& Peterson, 2002; Steinfield et al., 2008). They also support the cooperation and coordination of interest groups (Nie et al., 2010; Donath \& boyd, 2004; Wattal et al., 2010). Researchers have pointed out the potential of social media to create social capital (Ellison et al., 2007; McLeod et al., 1999; Zhang et al., 2009). In fact, membership in political groups on Facebook proved a strong predictor of offline political participation (Conroy et al., 2012). At the same time, these in-group dynamics may contribute to a fragmentation of audiences, partisan selectivity, and increasing homogenization within interest groups (Dahlgren, 2005; Bennett \& Iyengar, 2008). Research has shown that social encouragement increases use of information and communication technology (Venkatesh \& Davis, 2000; Venkatesh et al., 2003). Online association should therefore lead to more active online engagement while simultaneously being associated with the risk of a more polarized discourse (Scheufele et al., 2006; Nie et al., 2010; Hargittai et al., 2007).

Research Proposition 4: Informational and social Internet uses positive impact online association, that is, online engagement in interest groups.

Research Proposition 5: Online association is positively associated with users' propensity to engage corporations online.

Research has shown that online engagement and participation is not equally common among all segments of the population (Albrecht, 2006; Di Gennaro \& Dutton, 2006), resulting in a so-called 
Impact of online media on stakeholder engagement

'participation divide' (Hargittai \& Walejko, 2008). In terms of gender differences, most studies find that men are more active and eager to participate politically than women (Calenda \& Meijer, 2009; Di Gennaro \& Dutton, 2006). The effect of gender on online participation appears to be moderated by political interest, as studies indicate that men exhibit stronger interest in these matters (Gibson et al., 2005; Wang, 2007). We would propose that the same holds for users' interest in business affairs.

Age is another important demographic predictor of both online and offline participation (Bridges et al., 2012; Dahlgren, 2011; Jugert et al., 2013). In short, age positively impacts offline political participation (Wang, 2007; Gibson et al., 2005) but negatively impacts Internet use. Therefore, the overall effect of age on online political participation is ambivalent. Younger citizens tend to rely more heavily on online participation than on offline participation (Di Gennaro \& Dutton, 2006).

Finally, education and income, both indicators of social status, positively impact offline political participation (Wang, 2007) as well as online political participation (Gibson et al., 2005). Hargittai and Walejko (2008) found that higher social status is associated with more expressive Internet uses. As social status drives both political interest and Internet use, these effects compound when it comes to online participation (Di Gennaro \& Dutton, 2006: 305). Even among youth, male, higher status, and better educated citizens are more politically engaged online than their female, lower status, and less educated counterparts (Livingstone et al., 2005).
Research Proposition 6: Socio-demographic antecedents affect users' propensity to engage corporations online, with education and income exerting a positive and age exerting a negative influence on online engagement. Male users will be more likely to engage corporations online than their female counterparts.

In summary, studies in political and civic participation provide valuable insights into online participation. Based on these findings, we propose that Internet use bolsters online stakeholder engagement, which potentially translates into offline participation in corporate affairs. Our research propositions are summarized in the research framework laid out in Figure 3. This framework concurs with current findings identified by our literature analysis in the field of business participation, limited as it may be. We would posit that it is applicable to various stakeholder contexts, not only those of customers and shareholders, but also employees, local communities, or non-government organizations. It therefore provides a substantiated basis for future studies of the effect of online media on stakeholder engagement in corporate affairs and governance.

\section{SUMMARY AND DISCUSSION}

Our systematic literature review of studies addressing online participation and engagement revealed that, to date, stakeholders' online engagement in business governance has received little attention. Among the five topical categories identified in our analysis, only citizens' engagement in cultural and art projects has received less academic scrutiny than

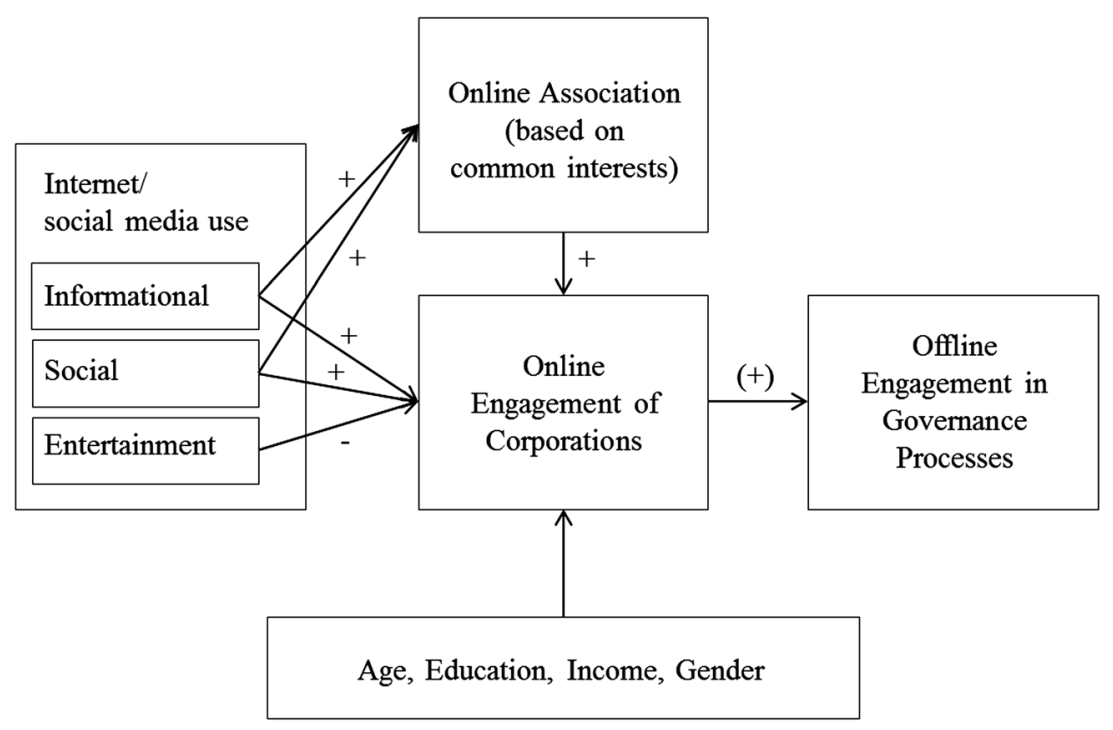

Figure 3 Model of new media effects on corporate governance 
the various forms of business participation. Political and civic engagement on the Internet, in turn, has emerged as an established and thriving field of inquiry in the course of the last decade.

Overall, we analyzed 162 papers addressing both business and political/civic participation. The studies of stakeholders' business engagement identified in this review exhibit a marked bias towards marketing issues. Attention has been directed towards the impact of new media on customer relationship management and customer service, expecting richer and more diverse interaction between consumers and corporations. A range of studies address the involvement of consumers in productive processes (open innovation, co-creation), leading to new, collaborative forms of value creation. Only in the case of creative industries has this development been critically scrutinized as to its effects on value redistribution.

Stakeholder participation beyond that of customers has received little attention in the current literature. Online media are seldom framed or analyzed as promising tools for engaging stakeholders such as employees, local communities, public institutions, or social groups and involving them in governance decisions. Our analysis revealed only few studies focusing on the impact of new media on stakeholder activism and critical engagement of corporations. One study, though, found that Internet use increases stock market participation, which may have significant implications for corporate governance.

In order to shed further light on the effect of online media on stakeholder engagement and governance, we turned to the more established field of online political and civic engagement. Here, we found strong evidence that Internet and social media use is in fact associated with higher levels of online and also offline engagement-although the latter effect appears weaker than the former. Social media, especially, support the identification and coordination of interest groups, which may result in more active engagement in corporate as well as civic affairs. Studies have found that users geared towards informational and social Internet uses are more likely to participate in civic and political matters. Research also indicates that online activists constitute a specific sample of the overall populace, exhibiting a bias towards male citizens of higher socioeconomic status. Online engagers, therefore, should not be considered representative of the overall population. Studies show that young, Internet-savvy citizens are especially attracted to online media as they provide new outlets or tools for issues engagement beyond established institutions.
These findings provide avenues for future research into the effect of new media on stakeholder engagement and corporate governance. Based on stakeholder theory, we have pointed out that a key function of corporate governance is the alignment of stakeholder interests. Stakeholders constitute coalitions of individuals united by a common interest (Cyert \& March, 1963; Donaldson \& Preston, 1995). These coalitions vie for a consideration of their interests in corporate decisions and actions-they strive to influence the corporate agenda (Noda \& Bower, 1996). Within this framework, corporate governance exhibits many similarities with the governance of public institutions. We conclude that, just as political interest groups employ social media in order to organize and affect the public agenda, social media can also facilitate the influence of stakeholder groups on the corporate agenda.

Current findings indicate that this effect is taking hold in customer or consumer relations: In the creative industries, particularly, corporations take note of emerging new services based on peer production and crowdsourcing, such as blogs (i.e., the Huffington Post), self-publishing (i.e., through Lulu), or vodcasting (i.e., through Youtube multichannel networks). In response to these new services, established providers strive to more closely monitor the sentiment of key audiences. An example of this trend would be newsrooms featuring wall-to-wall monitors displaying ongoing social media conversations and website analytics, thereby allowing for immediate editorial reactions to user sentiment. Even beyond the creative industries, companies actively invite their customers to provide input in order to more closely align current services with consumer wishes (e.g., Starbucks' outreach platform MyStarbucksIdea).

Through open innovation, customers are involved in the earliest phases of product development-and thereby shape the service portfolio of corporations. Findings indicate that social Internet uses are especially conducive to open innovation. In other words, corporations need to foster online communities of users in order to generate valuable input into their R\&D processes (Von Krogh et al., 2003). Reversely, consumers can best affect corporate decision making when they coordinate and organize their interests. One example would be the successful lobbying of customers for free Wi-Fi-services in all Starbucks stores on the MyStarbucksIdea-platform. We term this effect 'online association' in our framework.

Other examples of informational and social Web uses facilitating online association as a basis for the engagement of corporations can be found 
beyond consumer relations or mere product-related engagement of customers in instances of critical consumer engagement. Public affairs and public relations departments realize the need to closely monitor online conversations in social media as critical interest groups employ these media to organize demonstrations or boycotts. Platforms such as Avaaz.org serve to organize causes, crowdfunding platforms (i.e., Causes.com or Crowdrise.com) allow for such initiatives to generate tangible offline impact. Corporations establish social media monitoring divisions in order to more quickly respond to such critical stakeholder demands.

Of course, sites such as Awaaz.org or Causes.com also illustrate that stakeholders organizing online may not be socio-demographically representative of the overall customer base or even the overall population because younger and higher educated users appear overrepresented among their user base. Other examples indicating that stakeholders endowed with above average (social) capital may be able to generate more impact through online engagement can be found in the context of shareholder activism: recently, by critically commenting on the management of IT-corporation Apple on Twitter, US-Investor Carl Icahn caused a bump in share prices of up to $\$ 17 \mathrm{bn}$. Social interest groups would be hard press to employ social media to similar effects.

All of these examples indicate that social media can be expected to affect stakeholder engagement in corporate governance in a variety of domains. Yet, a number of contextual factors will moderate whether stakeholder engagement in social media will actually manage to impact the corporate agenda. There is still significant need for conceptual, qualitative, and quantitative research into these complex relationships. Case studies can help shed light on the preconditions of successful stakeholder engagement-both on the side of corporations and stakeholders. Open innovation research has already made significant progress in analyzing corporate antecedents of consumer engagement ('absorptive capacity') as well as best practices in the governance of engagement processes (Fey, 2005). Such findings would need to be expanded to other domains of stakeholder engagement, though (cf. O'Riordan \& Fairbrass, 2008; De Beer \& Rensburg, 2011).

Both qualitative and quantitative research should be conducted on the necessary motivations, resources, and competences of stakeholders actively engaging corporations online. The research framework developed in this analysis may help guide future empirical analyses of stakeholders' online engagement in corporate governance across a variety of issues, platforms, or contexts. All of its propositions require empirical scrutiny, including the effects of various Internet uses on online engagement in corporate affairs, socio-demographic antecedents, the facilitating role of online association, and of course moderators of the relationship between online and offline engagement in governance processes.

As to corporate engagement practices, active monitoring of stakeholder conversations in social media and participation in relevant online communities are increasingly adopted in order to strengthen organizational responsiveness. 'Boundary spanning' has long been described as a key task in stakeholder engagement and strategic management (Freeman, 1984). New media provide a new infrastructure especially conducive to boundary spanning. At the same time, top-down planning frameworks are still popular in corporate management (cf. Mintzberg, 1979). In order to fully realize online stakeholder engagement in corporate governance, practitioners need to re-conceptualize corporate governance as stakeholder interest alignment. Only based on such an understanding can the full potential of online stakeholder engagement be understood and its full rewards reaped.

\section{BIOGRAPHICAL NOTES}

Christian Hoffmann is an assistant professor at the Institute for Media and Communications Management, University of St. Gallen, Switzerland, and a lecturer at the University of Applied Sciences in Business Administration Zurich. His research is focused on online communication, social media, and political communication.

Christoph Lutz is a PhD student in media and communication atthe University of St. Gallen (Switzerland). His dissertation focuses on online participation, and his other research interests include social media in science and public administration, online privacy and trust, and digital serendipity.

\section{REFERENCES}

Adams C, Frost G. 2006. The internet and change in corporate stakeholder engagement and communication strategies on social and environmental performance. Journal of Accounting and Organizational Change 2(3): 281-303.

Albrecht, S. 2006. Whose voice is heard in online deliberation? A study of participation and representation in political debates on the internet. Information, Communication $\mathcal{E}$ Society 9(1): 62-82.

Andersen KN, Medaglia R, Vatrapu R, Henriksen HZ, Gauld R. 2011. The forgotten promise of e-government maturity: assessing responsiveness in the digital 
public sector. Government Information Quarterly 28(4): 439-445.

Andriof J, Waddock S. 2002. Unfolding stakeholder engagement. In Unfolding Stakeholder Thinking Theory, Responsibility and Engagement, Andriof J, Waddock S, Husted B, S Sutherland Rahman (Hrsg.). Greenleaf: Sheffield; 19-42.

Anduiza E, Cantijoch M, Gallego A. 2009. Political participation and the Internet: a field essay. Information, Communication \& Society 12(6): 860-878.

Bakker TP, de Vreese CH. 2011. Good news for the future? Young people, Internet use, and political participation. Communication Research XX(X): 1-20.

Bennett WL, Iyengar S. 2008. A New Era of minimal effects? The changing foundations of political communication. Journal of Communication 58(4): 707-731.

Bogan V. 2008. Stock market participation and the Internet. Journal of Financial and Quantitative Analysis 43(1): 191-211.

Boulianne S. 2009. Does internet Use affect engagement? A meta-analysis of research. Political Communication 26(2): 193-211.

Bridges F, Appel L, Grossklags J. 2012. Young adults' online participation behaviors: an exploratory study of web 2.0 use for political engagement. Information Polity 17: 163-176.

Burchell J, Cook J. 2008. Stakeholder dialogue and organisational learning: changing relationships between companies and NGOs. Business Ethics: A European Review 17(1): 35-46.

Calenda D, Meijer A. 2009. Young people, the Internet, and political participation. Information, Communication E Society 12(6): 879-898.

Campbell C, Piercy N, Heinrich D. 2012. When companies get caught: the effect of consumers discovering undesirable firm engagement online. Journal of Public Affairs 12(2): 120-126.

Carroll AB. 1979. A three dimensional model of corporate social performance. Academy of Management Review 4: 497-505.

Carroll AB, Buchholtz AK. 2006. Business \& Society. Ethics and Stakeholder Management. (6th ed.). Thomson: Mason, $\mathrm{OH}$.

Chaney D. 2012. The music industry in the digital age: consumer participation in value creation. International Journal of Arts Management 15(1): 42-69.

Chang C-C, Chen H-Y, Huang I-C. 2009. The interplay between customer participation and difficulty of design examples in the online designing. Cyberpsychology and Behavior 12(2): 147-154.

Clarkson MBE. 1995. A stakeholder framework for analyzing and evaluating corporate social performance. The Academy of Management Review 20(1): 92-117.

Cohen WM, Levinthal DA. 1990. Absorptive-capacity - a new perspective on learning and innovation. Administrative Science Quarterly 35(1): 128-152.

Conroy M, Feezell JT, Guerrero M. 2012. Facebook and political engagement: a study of online political group membership and offline political engagement. Computers in Human Behavior 28(5): 1535-1546.

Cyert, RM, March JG. 1963. A Behavioral Theory of the Firm. Prentice Hall: Englewood Cliffs.

Dabholkar PA, Sheng X. 2012. Consumer participation in using online recommendation agents: effects on satisfaction, trust, and purchase intentions. Service Industries Journal 32(9): 1433-1449.
Dahlgren P. 2005. The Internet, public spheres, and political communication: dispersion and deliberation. Political Communication 22(2): 147-162.

Dahlgren P. 2011. Young citizens and political participation online media and civic cultures. Taiwan Journal of Democracy 7(2): 11-25.

Davis R. 1999. The web of politics. The Internet's impact on the American political system. Oxford University Press: Oxford; 1-248.

Davis A. 2010. New media and fat democracy: the paradox of online participation. New Media $\mathcal{E}$ Society 12(5): 745-761.

De Beer E, Rensburg R. 2011. Toward a theoretical framework for the governing of stakeholder relationships: a perspective from South Africa. Journal of Public Affairs 11(4): 208-225.

Di Gennaro, C, Dutton W. 2006. The Internet and the public: online and offline political participation in the United Kingdom. Parliamentary Affairs 59(2): 299-313.

DiMaggio P, Hargittai E, Neuman R, Robinson J. 2001. Social implications of the Internet. Annual Review of Sociology 27: 307-336.

Donaldson T, Preston LE. 1995. The stakeholder theory of the corporation: concepts, evidence and implications. The Academy of Management Review 20(1): 65-91.

Donath J, Boyd d. 2004. Public displays of connection. BT Technology Journal 22(4): 71-82.

Dutta-Bergman MJ. 2006. Community participation and Internet Use after September 11: complementarity in channel consumption. Journal of Computer-Mediated Communication $\mathbf{1 1 .}$

Ebbers WE, Pieterson WJ, Noordman HN. 2008. Electronic government: rethinking channel management strategies. Government Information Quarterly 25(2): 181-201.

Ellison NB, Steinfield C, Lampe C. 2007. The benefits of Facebook "friends:" social capital and college students' use of online social network sites. Journal of ComputerMediated Communication 12(4): 1143-1168.

Fey CF. 2005. External sources of knowledge, governance mode, and R\&D performance. Journal of Management 31(4): 597-621.

Franquet R, Villa MI, Bergillos I. 2011. Audience participation in online news websites: a comparative analysis. Observatorio OBS 5(3): 223-242.

Freeman RE. 1984. Strategic Management - A Stakeholder Approach. Pitman: Boston.

Gibson RK, Lusoli W, Ward S. 2005. Online participation in the UK: testing a "contextualised" model of Internet effects. The British Journal of Politics and International Relations 7(4): 561-583.

Gil De Zuniga H, Veenstra A, Vraga E, Shah D. 2010. Digital democracy: reimagining pathways to political participation. Journal of Information Technology Politics 7(1): 36-51.

Goergen M. 2012. International Corporate Governance. Prentice Hall: Upper Saddle River.

Gulati R. 1998. Alliances and networks. Strategic Management Journal 19(4): 293-317.

Hacker KL. 1996. Missing links in the evolution of electronic democratization. Media, Culture Society 18: 213-232.

Hargittai E, Walejko G. 2008. The participation divide: content creation and sharing in the digital age. Information Communication Society 11(2): 239-256. 
Hargittai E, Gallo J, Kane M. 2007. Cross-ideological discussions among conservative and liberal bloggers. Public Choice 134(1-2): 67-86.

Harhoff D, Henkel J, Von Hippel E. 2003. Profiting from voluntary information spillovers: how users benefit by freely revealing their innovations. Research Policy 32(10): 1753-1769.

Heeks R, Bailur S. 2007. Analyzing e-government research: Perspectives, philosophies, theories, methods, and practice. Government Information Quarterly 24(2): 243-265.

Hertel G, Niedner S, Herrmann S. 2003. Motivation of software developers in Open Source projects: an Internet-based survey of contributors to the Linux kernel. Research Policy 32(7): 1159-1177.

Jennings MK, Zeitner V. 2003. Internet use and civic engagement: a longitudinal analysis. Public Opinion Quarterly 67(3): 311-334.

Jeppesen LB, Frederiksen L. 2006. Why do users contribute to firm-hosted user communities? The case of computer-controlled music instruments. Organization Science 17(1): 45-63.

Jugert P, Eckstein K, Noack P, Kuhn A, Benbow A. 2013. Offline and online civic engagement among adolescents and young adults from three ethnic groups. Journal of Youth and Adolescence 42(1): 123-35.

Kane GC, Fichman RG, Gallaugher J, Glaser J. 2009. Community Relations 2.0. Harvard Business Review 87(11): $45-51$.

Krick T, Forstater M, Monaghan P, Silannpää M, Van der Lugt C, Patridge K, Jackson C, Zohar A. 2005. From words to action. The stakeholder engagement manual. Volume 2: The Practitioner's Handbook on Stakeholder Engagement.

Krueger BS. 2002. Assessing the potential of Internet political participation in the United States: a resource approach. American Politics Research 30(5): 476-498.

Lakhani KR, Von Hippel E. 2003. How open source software works: "free" user-to-user assistance. Research Policy 32(6): 923-943.

Livingstone S, Bober M, Helsper E. 2005. Active participation or just more information? Information, Communication E Society 8(3): 287-314.

McLeod JM, Scheufele DA, Moy P. 1999. Community, communication, and participation: the role of mass media and interpersonal discussion in local political participation. Political Communication 16: 315-336.

Mintzberg H. 1979. Organizational power and goals: a skeletal theory. In Strategic Management - A New View of Business Policy and Planning, Schendel DE, Hofer CW (eds). Little, Brown and Company: Boston; 64-80.

Moy P, Manosevitch E, Stamm K, Dunsmore K. 2005. Linking dimensions of internet use and civic engagement. Journalism and Mass Communication Quarterly 82(3): 571-586.

Nguyen A. 2006. Journalism in the wake of participatory publishing. Australian Journalism Review 28(1): 47-59.

Nie NH, Miller IDW, Golde S, Butler DM, Winneg K. 2010. The World Wide Web and the U.S. political news market. American Journal of Political Science 54(2): 428-439.

Nisbet EC, Stoycheff E, Pearce KE. 2012. Internet use and democratic demands: a multinational, multilevel model of Internet Use and citizen attitudes about democracy. Journal of Communication 62(2): 249-265.
Noda T, Bower JL. 1996. Strategy making as iterated processes of resource allocation. Strategic Management Journal 17(Special Issue): 159-192.

O’Riordan L, Fairbrass J. 2008. Corporate social responsibility (CSR): models and theories in stakeholder dialogue. Journal of Business Ethics 83(4): 745-758.

Pedersen ER. 2006. Making corporate social responsibility (CSR) operable: How companies translate stakeholder dialogue into practice. Business and Society Review 111(2): 137-163.

Post JE, Preston LE, Sachs S. 2002. Managing the extended enterprise: the new stakeholder view. California Management Review 45(1): 6-28.

Powell WW, Koput KW, Smith-Doerr L. 1996. Interorganizational collaboration and the locus of innovation: networks of learning in biotechnology. Administrative Science Quarterly 41(1): 116-145.

Putnam RD. 1995. Bowling Alone: The Collapse and Revival of American Community. Simon \& Schuster: New York; 1-541.

Ramaswamy V. 2008. Co-creating value through customers' experiences: the Nike case. Strategy $\mathcal{E}$ Leadership 36(5): 9-14.

Riegner C. 2007. Word of mouth on the web: the impact of Web 2.0 on consumer purchase decisions. Journal of Advertising Research December, 436-447.

Roper J. 2002. Government, corporate or social power? The Internet as a tool in the struggle for dominance in public policy. Journal of Public Affairs 2(3): 113-124.

Rowson J, Broome S, Jones A. 2010. Connected Communities: How social networks power and sustain the Big Society. RSA Report.

Sashi CM. 2012. Customer engagement, buyer-seller relationships, and social media. Management Decision 50(1-2): 253-272.

Sawhney M, Verona G, Prandelli E. 2005. Collaborating to create: the internet as a platform for customer engagement in product innovation. Journal of Interactive Marketing 19(4): 4-17.

Scheufele DA, Hardy BW, Brossard D, Waismel-Manor IS, Nisbet E. 2006. Democracy based on difference: examining the links between structural heterogeneity, heterogeneity of discussion networks, and democratic citizenship. Journal of Communication 56(4): 728-753.

Shirky C. 2011. The political power of social media: technology, the public sphere, and political change. Foreign Affairs, Jan/Feb. Retrieved July, 2012 from http:// www.foreignaffairs.com/articles/67038/clay-shirky/thepolitical-power-of-social-media

Starbuck WH. 1983. Organizations as action generators. American Sociological Review 48(1): 91-102.

Steinfield C, Ellison N, Lampe C. 2008. Social capital, self-esteem, and use of online social network sites: a longitudinal analysis. Journal of Applied Developmental Psychology 29(6): 434-445.

Stern MJ, Dillman DA. 2006. Community participation, social ties, and use of the Internet. City $\mathcal{E}$ Community 5(4): 409-425.

Stromer-Galley J. 2000. Online interaction and why candidates avoid it. Journal of Communication 50(4): 111-132.

Stromer-Galley J, Foot KA. 2002. Citizen perceptions of online interactivity and implications for political campaign communication. Journal of Computer-Mediated Communication 8(1).

Tether BS. 2002. Who co-operates for innovation, and why - An empirical analysis. Research Policy 31(6): 947-967. 
Towner TL, Dulio DA. 2011. An experiment of campaign effects during the YouTube election. New Media $\mathcal{E}$ Society 13(4): 626-644.

Van den Broek TA, Ehrenhard ML, Langley DJ, Groen AJ. 2012. Dotcauses for sustainability: combining activism and entrepreneurship. Journal of Public Affairs 12(3): 214-223.

Venkatesh V, Davis FD. 2000. A theoretical extension of the technology acceptance model: four longitudinal field studies. Management Science 46(2): 186-204.

Venkatesh V, Morris MG, Davis GB, Davis FD. 2003. User acceptance of information technology: toward a unified view. MIS Quarterly 27(3): 425-478.

Vitak J, Zube P, Smock A, Carr CT, Ellison N, Lampe C. 2011. It's complicated: Facebook users' political participation in the 2008 election. Cyberpsychology, Behavior and Social Networking 14(3): 107-114.

Von Krogh G, Spaeth, S, Lakhani KR. 2003. Community, joining, and specialization in open source software innovation: a case study. Research Policy 32(7): 1217-1241.

Wang, S-I. 2007. Political use of the Internet, political attitudes and political participation. Asian Journal of Communication 17(4): 381-395.

Wattal S, Schuff D, Mandviwalla M, Williams CB. 2010. Web 2.0 and politics: the 2008 Us presidential election and an E-politics research agenda. MIS Quarterly 34(4): 669-688.

Wellman B, Quan Haase A, White J. 2001. Does the Internet increase, decrease, or supplement social capital? Social networks, participation, and community commitment. American Behavioral Scientist 45(3): 436-455.

White CS. 1997. Citizen participation and the Internet: prospects for civic deliberation in the information age. Social Studies 88(1): 23-28.

Wilson SM, Peterson LC. 2002. The anthropology of online communities. Annual Review of Anthropology 31(1): 449-467.

Woodly D. 2007. New competencies in democratic communication? Blogs, agenda setting and political participation. Public Choice 134(1-2): 109-123.

Yen HR. 2011. Good soldiers on the Web: understanding the drivers of participation in online communities of consumption. International Journal of Electronic Commerce 15(4): 89-120.

Zhang W, Johnson TJ, Seltzer T, Bichard SL. 2009. The revolution will be networked: the influence of social networking sites on political attitudes and behavior. Social Science Computer Review 28(1): 75-92. 